\title{
The Most Important Herbs Used in the Treatment of Sexually Transmitted Infections in Traditional Medicine
}

\section{Mohammadreza Nazer ${ }^{1}$, Saber Abbaszadeh ${ }^{2}$, Mohammd Darvishi $^{3}$, Abdolreza Kheirollahi ${ }^{4}$, Somayeh Shahsavari ${ }^{5}$, and Mona Moghadasi ${ }^{2}$}

\begin{abstract}
${ }^{1} \mathrm{MPH}$, Associate Professor, Department of Infectious Diseases, Lorestan University of Medical Sciences, Khorramabad, Iran

${ }^{2}$ Student Research Committee, Lorestan University of Medical Sciences, Khorramabad, Iran ${ }^{3}$ Associate Professor of Infectious Diseases, Infectious Research Center (IDTMRC), Department of Aerospace and Subaquatic Medicine, AJA University of Medical Sciences, Tehran, Iran ${ }^{4}$ Urology Specialist, Lorestan University of Medical Sciences, Khorramabad, Iran

${ }^{5}$ Biotechnology and Medicinal Plants Research Center, Ilam University of Medical Sciences, Ilam, Iran
\end{abstract}

Corresponding Author: Mohammd Darvishi; email: darvishim@gmail.com

Received 24 February 2019 Accepted 25 March 2019 Published 28 June 2019

Production and Hosting by Knowledge E

(c) Mohammadreza Nazer et al. This article is distributed under the terms of the

which permits unrestricted use and redistribution provided that the original author and source are credited.

Editor-in-Chief:

Prof. Mohammad A. M. Ibnouf

G OPEN ACCESS

\section{Abstract}

Sexually transmitted diseases (STDs) or venereal diseases are transmitted through various methods of sexual intercourse (oral, vaginal, and anal). The predisposition to this type of diseases and infections depends on the immunity system of the body, so the lower the immunity system's strength, the greater the risk of Sexually transmitted infections (STIS). The most important pathogenic causes of STIs include bacteria, viruses, and parasites. Phytochemical investigations have shown that medicinal plants are a rich source of antioxidant compounds, biologically active compounds, phenols, etc. They can have an inhibitory effect on germs and infectious viruses and are very important for a variety of parasitic diseases, microbial infections, and STIs. Some of the most important medicinal plants that produce inhibitory effects on the growth and proliferation of pathogenic agents of the STIs were reported in the present article. Based on the results obtained from the review of numerous articles indexed in the databases the Institute for Scientific Information, Scopus, PubMed, Google Scholar, etc., a number of plants have been reported to be used in the treatment and prevention of genital tract diseases and STIs, and to produce antiviral and antimicrobial effects, including Taxillus, Aristolochia, Syzygium cumini, Albizia adianthifolia, Bidens pilosa, Carica papaya, Ranunculus, Peltophorum africanum, Vachellia karroo, Rhoicissus tridentate, Houttuynia cordata, Panax notoginseng, Nelumbo nucifera, Astragalus, Hypericum aethiopicum, Spondias mombin, Jatropha zeyheri, Ximenia caffra, Trichilia dregeana, Clematis brachiate, Tabernaemontana, Sarcophyton. Phytochemical investigations have examined the therapeutic and clinical effects of medicinal plants, and the use of their active ingredients to produce herbal drugs has been addressed. The results of phytochemical investigations have shown that the most important compounds of these plants include quercetin, isoquercitrin, Dammarane-type saponin, flavonoids, alkaloids, flavonoids, glycosides, terpenoids, steroids, astragalosides, flavonoids and polysaccharides, $\alpha$-pinene, $\beta$-pinene, $\alpha$-pinene, quercetin, myricetin and luteolin flavonoids, $\beta$-pinene, 1,3,8-p-menthatriene, ledene, m-menthane, linalyl acetate and 
3-carene. $\beta$-sitosterol, lupeol, lupeol, sitosterol, spathulenol, $\beta$-sitostenone, $\gamma$-sitosterol, stigmasterol. Due to the main active ingredients and flavonoids of these plants, they can be used to produce herbal drugs that reduce genital tract (microbial, viral, and fungal) infections and STIs, and therefore reduce pain and suffering in patients.

Keywords: sexually transmitted infections, genital tract infections, antibacterial and antiviral medicinal plants, medicinal plants, natural antioxidants

\section{Introduction}

Sexually transmitted diseases (STDs) or infections (STIS) or venereal diseases are umbrella terms to refer to various diseases that are transmitted through various methods of sexual intercourse (oral, vaginal, and anal). Some of these diseases are transmitted via other routes than sexual intercourse [1-5]. STDs may be caused by bacteria, virus, or parasite. The symptoms, transmission routes, and treatment methods of the STDs are different [6-9]. Almost all people are predisposed to STDs, and the lower the strength of their immune system, the more likely they are to develop STDs [10-13].

Using certain devices such as condoms can reduce the risk of developing STDs, but there are no fault-free and completely safe methods to prevent the development of these diseases. Some diseases, such as hepatitis, can be transmitted through a contact with the infected person's blood without sexual intercourse, but some other diseases, such as gonorrhea, are transmitted only through sexual intercourse [11-14].

The most important STIs, which are caused by bacteria, can be easily treated with antibiotics. Chlamydia; gonorrhea, syphilis. Chlamydia: Chlamydia is a bacterial infection affecting the genital tract [15-18]. Viral STDs: Some STDs are caused by viral pathogens that are much more difficult or even impossible to cure. Their symptoms can rarely be eliminated; hepatitis $B$, hepatitis $C$, herpes simplex virus (HSV), human immunodeficiency virus (HIV), human papillomavirus (HPV), and genital warts. HIV infection is caused by the human immunodeficiency virus. HIV affects the ability of the body to fight viruses, bacteria, and fungi that develop during the disease and can lead to AIDS. AIDS is a life-threatening disease [19-22]. Parasitic STDs: Some STDs are caused by parasitic agents. This kind of STDs are caused by sexual intercourse or through close contact with the skin, including scabies, trichomonas, and pubic lice [23-25]. Trichomonas is one of the most common STDs caused by a microscopic parasite called Trichomonas 
vaginalis. The disease is transmitted and spread through sexual intercourse in people who are predisposed to infectious diseases. This disease most often affects the urethra in men and vagina in women but is usually asymptomatic [26-29].

\subsection{Vaginal infections}

Vaginal infection: A vaginal infection has symptoms similar to those of an STD, but it is not classified as an STD. Genital and urinary tract infections: Genital and urinary tract infections are uninvited guests of any woman's body [30-33]. The secretions and infections of the female reproductive system: Abnormal increase in vaginal discharge is due to a variety of reasons, commonly referred to as vaginitis $[34,35]$

\section{A. Vaginal yeast infections}

In women's vagina, yeast normally lives in small amounts, and the acidic environment of the vagina prevents the growth of the yeast. Now, if the acidity of the vaginal environment is reduced for some reason, the yeast will grow and lead to vaginal yeast infection. Various genital tract infections are among the common diseases that many women at a wide variety of ages may develop, especially vaginal yeast infection, which is more likely to develop during pregnancy [36-38].

\section{B. Bacterial vaginitis}

The vaginal environment contains a type of bacterium known as good vaginal bacterium and also another bacterium called anacrobes. Sometimes, without a specific cause, this bacterium grows excessively and leads to illness [39-41]. The best treatment for STIs (microbial and fungal) is herbal medicinesthat have the greatest therapeutic effect with the least side effects. To treat the genital yeast infection, the recommendations of traditional medicine can be followed [42-44].

Some of the therapeutic methods and medications recommended by traditional medicine across the world for STIs and genital tract infections are as follows:

\subsubsection{Herbal treatments for STIs and genital tract infections}

Apple vinegar, Apple vinegar is a very strong antibiotic and disinfectant agent, and its antibacterial and antifungal properties boost the immune system of the body against 
pathogens [45-48]. Rosemary, Rosemary is an anti-inflammatory and antibacterial plant, and therefore is used to treat various types of infections. The easiest way to exploit rosemary properties is to use the tea or oily extract of the plant [49-52]. Garlic, Garlic is a natural, highly effective antibiotic for the treatment of various infections and its antibacterial properties are microbicidal. The extract of this plant eliminates vaginal yeast infections and reduces pain [53-56]. Treating gynecological infections by using tea tree oil, Tea tree oil treats the infection with its strong antibacterial, antifungal, and antimicrobial properties [57-59]. Basil leaf, Basil leaf is a strong microbicide and can destroy a variety of fungi and bacteria [60-62]. Aloe vera, The use of $A$. vera and its gel is effective in treating infection and remove itching. The nectar of the plant is effective to remove itching caused by the infection in the genitalia [63-66]. Blueberries, Blueberries are fruits that have many usages in traditional medicine and are recommended to prevent urinary tract illnesses. One of the chemical compounds of the fruit is a kind of substance called PACS that can kills the bacteria that causes the infection in the body and prevents their proliferation and accumulation. Eating blueberries is effective to get rid of fungal infection [67-70]. Oak, Oak tree bark and leaves contain tannin, sugar, gallic acid, malic acid, quercetin, mucilage, pectin, resin, and oil. Therefore, this plant has a very strong antibacterial property and produces strong effects in reducing and treating genital tract bacterial diseases and STIs [71-74]. Eucalyptus, Eucalyptus essential oil exhibits antimicrobial properties against certain bacteria. In general, the antimicrobial effects of this plant are comparatively greater on gram-positive bacteria. In some cases, eucalyptus has been prescribed for the treatment of gonorrhea, with very promising results [73-77]. Silybum marianum, S. marianum is also one of the herbal drugs that are used for treating STDs with traditional form of medicine. The $S$. marianum is rich in silymarin (a natural material that can destroy $T$. vaginalis), which makes the plant an ideal choice to fight against certain types of STDs. In addition, this substance is also used to boost the immune system of the body and therefore helps fight the parasite that causes infection in the body [78-81]. Soma, Soma is known as one of the effective traditional and herbal drugs as well as a home remedy for STDs due to its potent antibacterial properties. Leaves, tree bark, roots, and fruit of soma have high pharmaceutical value, and its anti-inflammatory and antibacterial properties will certainly help fight certain diseases like gonorrhea and syphilis. In addition, soma contains saponin, which consists of phytochemicals (plant chemicals) that help kill all types of germs, boost the immune system, and restore the body [82-85]. 


\section{Methods}

The data used in this review were obtained from scientific articles indexed in the databases such as Iran Medex, Irandoc, ISI, PubMed, Scopus, Web of Science, Scientific Information Database, Magiran, Google Scholar, etc., that were retrieved using the search terms: sexually transmitted infections, genital tract infections, antibacterial and antiviral drugs, medicinal herbs and natural antioxidants, medicinal herbs effective on genital tract microbial infections, medicinal herbs effective on genital fungal infection, medicinal herbs effective on genital viral infections, effects of herbal therapy on sexually transmitted infections, antibacterial and antifungal effects of plant extracts and essential oils.

In this review article, a total of 190 papers were reviewed. After the preliminary review, 70 articles were found to be eligible for the subject of our study. Relevant articles were included and irrelevant ones excluded. Finally, 70 articles were found to be related to the purpose of our study and were selected.

\section{Results}

Medicinal plants that were reported in this review are very important for the treatment and prevention of various types of parasitic and microbial infections and STIs (Table 1).

Based on the results obtained from our review of numerous articles, a number of plants have been reported to be used in the treatment and prevention of genital tract diseases and STIs, and to produce antiviral and antimicrobial effects, including Taxillus, Aristolochia, Syzygium cumini, Albizia adianthifolia, Bidens pilosa, Carica papaya, Ranunculus, Peltophorum africanum, Vachellia karroo, Rhoicissus tridentate, Houttuynia cordata, Panax notoginseng, Nelumbo nucifera, Astragalus, Hypericum aethiopicum, Spondias mombin, Jatropha zeyheri, Ximenia caffra, Trichilia dregeana, Clematis brachiate, Tabernaemontana, Sarcophyton.

Additional information on the pharmaceutical and therapeutic plants and also their details are given in Table 1.

The results of phytochemical investigations have shown that the most important compounds of the plants include: total flavonoids and phenolics, steroids, Alkaloids, quercetin, isoquercitrin, Dammarane-type saponin, flavonoids, alkaloids, flavonoids, 
glycosides, terpenoids, steroids, astragalosides, flavonoids and polysaccharides, $\alpha$ pinene, $\beta$-pinene, $\alpha$-pinene, quercetin, myricetin and luteolin flavonoids, $\beta$-pinene, 1,3,8p-menthatriene, ledene, m-menthane, linalyl acetate and 3-carene, $\beta$-sitosterol, Iupeol, $\beta$, sitosterol, spathulenol, $\beta$-sitostenone, $\gamma$-sitosterol, stigmasterol., phenolic acid and flavonoids.

The most important active ingredients and important flavonoids of these plants are shown in Table 2.

TABLE 1:

\begin{tabular}{|c|c|c|c|c|c|c|}
\hline $\begin{array}{l}\text { Scientific } \\
\text { Name }\end{array}$ & Family Name & $\begin{array}{l}\text { Part of } \\
\text { plant }\end{array}$ & Type affect & $\begin{array}{l}\text { Common } \\
\text { Name }\end{array}$ & Therapeutic effect & Ref. \\
\hline Taxillus & Loranthaceae & Branch & $\begin{array}{l}\text { Ethanolic } \\
\text { extract }\end{array}$ & Taxillus & $\begin{array}{l}\text { Ethanol extract of this plant } \\
\text { has high antioxidant } \\
\text { properties and significantly } \\
\text { decreases the expression } \\
\text { of mRNA, iNOS, and COX-2 } \\
\text { by induction of LPS, } \\
\text { followed by the reduction } \\
\text { of NO and PGE2 } \\
\text { production. It also has an } \\
\text { effect on the regulation of } \\
\text { inflammatory cytokines } \\
\text { such as IL- } 1 \beta \text { TNF- } \alpha \text {, and } \\
\text { because of LPS it reduces } \\
\text { the expression of IL-1 } \beta \text { too } \\
\text { much. Concentrations of } \\
50 \mu g / m l \text { suppress the } \\
\text { expression of TNF- } \alpha \text {, which } \\
\text { is why an anti-inflammatory } \\
\text { agent is known to be } \\
\text { infectious. }\end{array}$ & \\
\hline Aristolochia & Aristolochiace & Aerial part & $\begin{array}{l}\text { Aqueous } \\
\text { and } \\
\text { Ethanolic } \\
\text { extract }\end{array}$ & Pipevine & $\begin{array}{l}\text { The antiparasitic property } \\
\text { of this plant can be made } \\
\text { through a genome such } \\
\text { that compounds that cause } \\
\text { damage to DNA are often } \\
\text { known as antimicrobial, } \\
\text { antimicrobial, and } \\
\text { cytotoxic. General damage } \\
\text { to DNA occurs when } \\
\text { alkylating agents attach to } \\
\text { DNA by covalent bonding if } \\
\text { the enzymatic repair of } \\
\text { DNA does not resolve the } \\
\text { alkalinity. Spot mutations, } \\
\text { removal, or alteration of the } \\
\text { mold in parenchyma, } \\
\text { which, if located in } \\
\text { important protein regions, } \\
\text { can cause the parasite to } \\
\text { die. }\end{array}$ & 90 \\
\hline
\end{tabular}




\begin{tabular}{|c|c|c|c|c|c|c|}
\hline $\begin{array}{l}\text { Scientific } \\
\text { Name }\end{array}$ & Family Name & $\begin{array}{l}\text { Part of } \\
\text { plant }\end{array}$ & Type affect & $\begin{array}{l}\text { Common } \\
\text { Name }\end{array}$ & Therapeutic effect & Ref. \\
\hline $\begin{array}{l}\text { Syzygium } \\
\text { cumini }\end{array}$ & Myrtaceae & Aerial part & $\begin{array}{l}\text { Methanolic } \\
\text { extract }\end{array}$ & Black plum & $\begin{array}{l}\text { The methanolic extract of } \\
\text { this plant has antibacterial } \\
\text { effects against } E \text {. coli and } \\
\text { Pseudomonas aeragenase } \\
\text { that cause urinary tract } \\
\text { infections and sexually } \\
\text { transmitted infections. This } \\
\text { plant with a concentration } \\
\text { of } 4 \mathrm{mg} / \mathrm{disc} \text {, on average, } \\
\text { has an inhibition zone of } \\
23 \mathrm{~mm} \text { in } E \text {. Coli and } 18 \\
\mathrm{~mm} \text { in Pseudomonas in the } \\
\text { disc-diffusion method, also } \\
\text { in the MIC method in both } \\
\text { bacteria at a concentration } \\
\text { of } 1.5 \mathrm{mg} / \mathrm{ml} \text {. }\end{array}$ & 91 \\
\hline $\begin{array}{l}\text { Albizia } \\
\text { adianthifolia }\end{array}$ & Fabaceae & Crust & $\begin{array}{l}\text { Aqueous } \\
\text { extract }\end{array}$ & Flat-crown & $\begin{array}{l}\text { The blueberry extract of } \\
\text { the bark with a } \\
\text { concentration of } 100 \mu \mathrm{g} / \mathrm{ml} \\
\text { has anti-bacterial, } \\
\text { anti-microbial properties, } \\
\text { and inhibits prostaglandin } \\
\text { synthesis and increases } \\
\text { cell activity as a result of } \\
\text { the treatment of } \\
\text { STl-induced ulcers. } \\
\text { Effective Nissiagonuria with } \\
\text { MIC } 6 / 45 \mathrm{mg} / \mathrm{ml} \text {. }\end{array}$ & 92 \\
\hline $\begin{array}{l}\text { Bidens } \\
\text { pilosa }\end{array}$ & Asteraceae & Leaf & $\begin{array}{l}\text { Aqueous } \\
\text { extract }\end{array}$ & Black-jack & $\begin{array}{l}\text { The extract of the leaves of } \\
\text { this plant has a } \\
\text { concentration of } 100 \mu \mathrm{g} / \mathrm{ml} \\
\text { effective on syphilis, but it } \\
\text { is not effective in the short } \\
\text { term. This plant has } \\
\text { anti-malarial properties, } \\
\text { prostaglandin synthesis } \\
\text { inhibitor, anti-inflammatory, } \\
\text { anti-fungal and } \\
\text { antibacterial agents, } \\
\text { accelerated cell activity, } \\
\text { and wound healing. The } \\
\text { effect of STI on Neisseria } \\
\text { gonorrhoeae is U. } \\
\text { urealyticum-O. ureolytica. } \\
\text { The mean MIC of mg/ml is } \\
83.2 \text {. }\end{array}$ & 92 \\
\hline $\begin{array}{l}\text { Carica } \\
\text { papaya }\end{array}$ & Caricaceae & Leaf & $\begin{array}{l}\text { Aqueous } \\
\text { extract }\end{array}$ & Papaya & $\begin{array}{l}\text { Blue leaf extract of this } \\
\text { plant is effective against } \\
\text { Candida infection - STI } \\
\text { gonorrhea, antimicrobial, } \\
\text { bacteriostatic activity, } \\
\text { antimalarial, and an } \\
\text { average MIC of } 13.1 \mathrm{mg} / \mathrm{ml} \text {. }\end{array}$ & 92 \\
\hline
\end{tabular}




\begin{tabular}{|c|c|c|c|c|c|c|}
\hline $\begin{array}{l}\text { Scientific } \\
\text { Name }\end{array}$ & Family Name & $\begin{array}{l}\text { Part of } \\
\text { plant }\end{array}$ & Type affect & $\begin{array}{l}\text { Common } \\
\text { Name }\end{array}$ & Therapeutic effect & Ref. \\
\hline Ranunculus & Ranunculacea! & Leaf & $\begin{array}{l}\text { Aqueous } \\
\text { extract }\end{array}$ & & $\begin{array}{l}\text { The aqueous extract of the } \\
\text { leaf of this plant has an } \\
\text { effect on } U \text {. urealyticum } \\
\text { ( } 0.02 \mathrm{mg} / \mathrm{ml} \text { ), which has } \\
\text { antimicrobial properties, } \\
\text { and } \mathrm{MIC} \text { is } 73 \mathrm{mg} / \mathrm{ml} \text {. }\end{array}$ & 92 \\
\hline $\begin{array}{l}\text { Peltophorum } \\
\text { africanum }\end{array}$ & Fabaceae & Root & $\begin{array}{l}\text { Aqueous } \\
\text { extract }\end{array}$ & $\begin{array}{l}\text { Weeping } \\
\text { wattle }\end{array}$ & $\begin{array}{l}\text { The root extract of this } \\
\text { plant is used at } \\
\text { concentration }(0.04 \mathrm{mg} / \mathrm{ml}) \\
\text { in the treatment of } \\
\text { Venereal diseases and } \\
\text { cephalyses. It is } \\
\text { antibacterial and antiviral } \\
\text { and acts against } U \text {. } \\
\text { urealyticum. MIC: } 2.68 \\
\mathrm{mg} / \mathrm{ml} \text {. }\end{array}$ & 92 \\
\hline $\begin{array}{l}\text { Vachellia } \\
\text { karroo }\end{array}$ & Fabaceae & Root & $\begin{array}{l}\text { Ethanolic } \\
\text { extract }\end{array}$ & Sweet thorn & $\begin{array}{l}\text { The ethanolic extract of } \\
\text { this plant has antibacterial } \\
\text { properties and also has an } \\
\text { anthraquinones secondary } \\
\text { composition, which is used } \\
\text { in the treatment of STD } \\
\text { and has the highest effect } \\
\text { on Neisseria gonorrhoea } \\
\text { and } \mathrm{Klebsiella} \text { with MIC0 } / 8 \\
\mathrm{mg} / \mathrm{ml} \text {. The IC50 values are } \\
0 / 83 \mu \mathrm{g} / \mathrm{ml} \text {. }\end{array}$ & 93 \\
\hline $\begin{array}{l}\text { Rhoicissus } \\
\text { tridentate }\end{array}$ & Vitaceae & Root & $\begin{array}{l}\text { Ethanolic } \\
\text { extract }\end{array}$ & Rhoicissus & $\begin{array}{l}\text { The ethanolic extract of the } \\
\text { plant is effective in treating } \\
\text { bladder infection and has a } \\
\text { secondary composition of } \\
\text { alkaloids, flavonoids, } \\
\text { tannins. It also has } \\
\text { antifungal and antioxidant } \\
\text { properties and has an } \\
\text { effect on E.coli and } \\
\text { Candida albicans with an } \\
\text { MIC of } 0.8 \text {. IC50 values are } \\
0.06 \mu \mathrm{g} / \mathrm{ml} \text {. }\end{array}$ & 94 \\
\hline $\begin{array}{l}\text { Houttuynia } \\
\text { cordata }\end{array}$ & Saururaceae & Aerial part & $\begin{array}{l}\text { Aqueous } \\
\text { extract }\end{array}$ & Fish leaf & $\begin{array}{l}\text { The aqueous extract of this } \\
\text { plant is effective in the } \\
\text { treatment of HSV. Its } \\
\text { effective compounds } \\
\text { include quercetin, } \\
\text { isoquercitrin. This plant has } \\
\text { a concentration of } 100 \mu \mathrm{M} \\
\text { by inhibiting the activity of } \\
\text { NF-kB as well as blocking } \\
\text { the binding of the virus, its } \\
\text { penetration and } \\
\text { proliferation. IC } 50(\mu \mathrm{g} / \mathrm{mL}) \\
\text { is } 692 \text { and the CC } 50 \mu \mathrm{g} / \mathrm{mL} \\
\text { is more than } 100,000 \text {. }\end{array}$ & 95 \\
\hline
\end{tabular}




\begin{tabular}{|c|c|c|c|c|c|c|}
\hline $\begin{array}{l}\text { Scientific } \\
\text { Name }\end{array}$ & Family Name & $\begin{array}{l}\text { Part of } \\
\text { plant }\end{array}$ & Type affect & $\begin{array}{l}\text { Common } \\
\text { Name }\end{array}$ & Therapeutic effect & Ref. \\
\hline $\begin{array}{l}\text { Panax } \\
\text { notoginseng }\end{array}$ & Araliaceae & Root & $\begin{array}{l}\text { Aqueous } \\
\text { extract }\end{array}$ & $\begin{array}{l}\text { Chinese } \\
\text { ginseng }\end{array}$ & $\begin{array}{l}\text { This plant contains the } \\
\text { ST- } 4 \text { notoginsenoside } \\
\text { compound and the extract } \\
\text { is made from the root. It is } \\
\text { a Dammarane-type } \\
\text { saponin that prevents } \\
\text { HSV-1 penetration and viral } \\
\text { protein synthesis (vp5) and } \\
\text { replicates the HSV virus. } \\
\text { The IC } 50(\mu \mathrm{g} / \mathrm{mL}) \text { is } 67.0 \pm \\
16.4 \text { and the } \mathrm{mean} \text { CC } 50 \text { is } \\
56.4 \pm 510.5 \mu \mathrm{g} / \mathrm{mL} \text {. }\end{array}$ & 95 \\
\hline $\begin{array}{l}\text { Nelumbo } \\
\text { nucifera }\end{array}$ & Nelumbonace & i Aerial part & $\begin{array}{l}\text { Aqueous } \\
\text { extract }\end{array}$ & Indian lotus & $\begin{array}{l}\text { The extract of this plant } \\
\text { discontinues } \\
\alpha \text { TIF/C1/Oct-1/GARAT } \\
\text { multiprotein, decreases the } \\
\text { expression of ICPO } \\
\text { (infected cell polypeptide } \\
\text { 0) and ICP4, forms the } \\
\text { DNA complex and is } \\
\text { effective in the treatment of } \\
\text { HSV. The IC5O }(\mu \mathrm{g} / \mathrm{mL}) \text { is } \\
21.3 \pm 1.6 \mu \mathrm{g} / \mathrm{mL} \text {. }\end{array}$ & 95 \\
\hline Astragalus & Fabaceae & Aerial part & $\begin{array}{l}\text { Aqueous } \\
\text { extract }\end{array}$ & Milkvetch & $\begin{array}{l}\text { This plant has a } \\
\text { composition of astragalus } \\
\text { polysaccharide and } \\
\text { polysaccharide. It acts on } \\
\text { the TLR3/NF-kB signaling } \\
\text { pathway and increases the } \\
\text { expression of TNF } \alpha \text {-IL- } 6 \text {. } \\
\text { CC50 } \mu \mathrm{g} / \mathrm{mL} \text { is } 120 \text {. This } \\
\text { plant does not directly } \\
\text { affect the virus, but it } \\
\text { protects against astrocytes } \\
\text { by increasing the immune } \\
\text { function of the body } \\
\text { against HSV. }\end{array}$ & 95 \\
\hline $\begin{array}{l}\text { Hypericum } \\
\text { aethiopicum }\end{array}$ & Hypericaceae & Root & $\begin{array}{l}\text { Ethanolic } \\
\text { and } \\
\text { aqueous } \\
\text { extract }\end{array}$ & $\begin{array}{l}\text { Saint John's } \\
\text { wort }\end{array}$ & $\begin{array}{l}\text { The aqueous and alcoholic } \\
\text { extract of this plant with a } \\
\text { concentration of } 0.3 \mathrm{mg} / \mathrm{ml} \\
\text { against Neisseria } \\
\text { gonorrhoeae has the } \\
\text { highest sensitivity in the } \\
\text { concentration of } 0.2 \mathrm{mg} / \mathrm{ml} \\
\text { to Gardnerella vaginalis. } \\
\text { The alcoholic extract of this } \\
\text { plant is more effective than } \\
\text { blue. }\end{array}$ & 96 \\
\hline
\end{tabular}




\begin{tabular}{|c|c|c|c|c|c|c|}
\hline $\begin{array}{l}\text { Scientific } \\
\text { Name }\end{array}$ & Family Name & $\begin{array}{l}\text { Part of } \\
\text { plant }\end{array}$ & Type affect & $\begin{array}{l}\text { Common } \\
\text { Name }\end{array}$ & Therapeutic effect & Ref. \\
\hline $\begin{array}{l}\text { Spondias } \\
\text { mombin }\end{array}$ & Anacardiacea€ & $\in$ Leaf & $\begin{array}{l}\text { Methanolic } \\
\text { extract }\end{array}$ & $\begin{array}{l}\text { Yellow } \\
\text { mombin }\end{array}$ & $\begin{array}{l}\text { The leaf methanolic extract } \\
\text { of this plant has good } \\
\text { effects on S. pyogenes, } S \text {. } \\
\text { typhi., E. coli, and } S \text {. } \\
\text { aureus, and the phenolic } \\
\text { acid present in the } \\
\text { antibacterial effects against } \\
B \text {. cereus, S. pyogenes, } \\
\text { and Mycobacterium } \\
\text { fortuitum. The MIC for B. } \\
\text { cereus is } 62.5 \mu \mathrm{g} / \mathrm{ml} \text { and } \\
\text { for the rest of the bacteria } \\
\text { more than } 1000 \text {. }\end{array}$ & 97 \\
\hline $\begin{array}{l}\text { Jatropha } \\
\text { zeyheri }\end{array}$ & Euphorbiaceat & \& Root & Extract & Nettlespurge & $\begin{array}{l}\text { Estonian root extract of this } \\
\text { plant has a good effect on } \\
\text { STI and against Candida } \\
\text { albicans and Cryptococcus } \\
\text { neoformans. It has a great } \\
\text { effect on MIC } 0.20 \mathrm{mg} / \mathrm{ml} \\
\text { for each bacterial strain. }\end{array}$ & 98 \\
\hline $\begin{array}{l}\text { Ximenia } \\
\text { caffra }\end{array}$ & Olacaceae & Root & $\begin{array}{l}\text { Aqueous } \\
\text { extract }\end{array}$ & Mtundakula & $\begin{array}{l}\text { The aqueous extract of the } \\
\text { root of this plant is effective } \\
\text { on } U \text {. urealyticum, O. } \\
\text { ureolytica, and } N \text {. } \\
\text { gonorrhoeae with an } \\
\text { average MIC of } 61.2 \mathrm{mg} / \mathrm{ml} \\
\text { and is used in the } \\
\text { treatment of venereal } \\
\text { diseases and STI. It has } \\
\text { antibacterial, antimalarial, } \\
\text { and antiinflammatory } \\
\text { properties. }\end{array}$ & 99 \\
\hline $\begin{array}{l}\text { Trichilia } \\
\text { dregeana }\end{array}$ & Meliaceae & Whole plant & $\begin{array}{l}\text { Aqueous } \\
\text { extract }\end{array}$ & $\begin{array}{l}\text { Forest natal- } \\
\text { mahogany }\end{array}$ & $\begin{array}{l}\text { The aqueous extract of this } \\
\text { plant is used in the } \\
\text { treatment of gonorrhea A } \\
\text { and syphilis with an } \\
\text { average } \mathrm{MIC} \text { of } 2 \mathrm{mg} / \mathrm{ml} \text {. } \\
\text { This plant inhibits } \\
\text { prostaglandin synthesis } \\
\text { and is used as } \\
\text { anti-inflammatory, } \\
\text { antibacterial, and microbial } \\
\text { agents. }\end{array}$ & 99 \\
\hline $\begin{array}{l}\text { Clematis } \\
\text { brachiata }\end{array}$ & Ranunculacea & Leaf & $\begin{array}{l}\text { Aqueous } \\
\text { extract }\end{array}$ & Traveller's joy & $\begin{array}{l}\text { Blue leaf extract of this } \\
\text { plant is used to treat } \\
\text { syphilis. This plant inhibits } \\
\text { prostaglandin synthesis } \\
\text { and is antimalarial. The } \\
\text { mean MIC is } 4.05 \mathrm{mg} / \mathrm{ml} \text {. }\end{array}$ & 99 \\
\hline Tabernaemo & I Apocynaceae & Crust & $\begin{array}{l}\text { Aqueous } \\
\text { extract }\end{array}$ & Milkwood & $\begin{array}{l}\text { The aqueous extract of this } \\
\text { plant has anti-fungal, } \\
\text { cytotoxic, antibacterial, and } \\
\text { antimycobacterial } \\
\text { properties. The mean MIC } \\
\text { is } 2 / 44 \mathrm{mg} / \mathrm{ml} \text {. }\end{array}$ & 99 \\
\hline
\end{tabular}




\begin{tabular}{|c|c|c|c|c|c|c|}
\hline $\begin{array}{l}\text { Scientific } \\
\text { Name }\end{array}$ & Family Name & $\begin{array}{l}\text { Part of } \\
\text { plant }\end{array}$ & Type affect & $\begin{array}{l}\text { Common } \\
\text { Name }\end{array}$ & Therapeutic effect & Ref. \\
\hline Sarcophyton & Orchidaceae & Stem & $\begin{array}{l}\text { Aqueous } \\
\text { extract }\end{array}$ & Sarcophyton & $\begin{array}{l}\text { Blue stem extract of this } \\
\text { plant is used in the } \\
\text { treatment of non-related } \\
\text { infections with HIV/AIDS } \\
\text { and gonorrhea, and has } \\
\text { the antibacterial properties } \\
\text { of treatment of wound } \\
\text { infection and diarrhea and } \\
\text { dysentery. MIC average is } \\
2.69 \mathrm{mg} / \mathrm{ml} \text {. }\end{array}$ & 99 \\
\hline
\end{tabular}

\section{Discussion}

Obtaining information on STDs and the methods of their prevention and treatment is one of the most important issues that everyone should be aware of. Fortunately, today, with the developments in technology and the promotion of human knowledge and science, many people around the world have become aware of these diseases, or at least they have become familiar with the methods of their prevention and treatment in modern medicine; however, therapeutic methods of traditional medicine and herbal supplements to treat common sexual and genital tract diseases are very important in this regard [1-7, 96-103]. The phenolic and antioxidant compounds in different organs of plants produce strong antioxidant, antiinflammatory, antispasmodic, antiseptic, and antimicrobial effects [8-10, 96-104].

Studies have shown that the plants Taxillus, Aristolochia, Syzygium cumini, Albizia adianthifolia, Bidens pilosa, Carica papaya, Ranunculus, Peltophorum africanum, Vachellia karroo, Rhoicissus tridentate, Houttuynia cordata, Panax notoginseng, Nelumbo nucifera, Astragalus, Hypericum aethiopicum, Spondias mombin, Jatropha zeyheri, Ximenia caffra, Trichilia dregeana, Clematis brachiate, Tabernaemontana, Sarcophyton play an important role in the treatment of parasitic and infectious diseases including STIs, genital and urinary tract infections, gastroenteritis, digestive cancer, constipation, flatulence and other genital tract diseases, sexual disorders, and cancers [86-95].

As the phytochemical and pharmaceutical investigations on the herbs mentioned in this study have indicated, they contain phenolic and antioxidant compounds and are very important for various types of parasitic diseases, microbial infections, and STIs. However, the exact mechanism of these plants remains to be elucidated [107-110]. Medicinal plants studied are important for the evaluation of antimicrobial, antifungal, and antiviral activity in infectious diseases. Therefore, various medicinal plants may produce effects through more than one specific mechanism [111-114]. The results of 
TABLE 2: Effective material of the herbal plants.

\begin{tabular}{|c|c|}
\hline Scientific Name & Effective material \\
\hline Taxillus & Flavonoid, avicularin, hyperin, quercitrin and taxillusin \\
\hline Aristolochia & Aristolochic acid \\
\hline Syzygium cumini & Coumarin, flavonoids, glycosides, phenols, tannins, steroids \\
\hline Albizia adianthifolia & $\begin{array}{l}\text { 1-methyl- } \beta \text {-carboline, }(+)-(\mathrm{R}) \text {-1-methyl-1,2,3,4-tetrahydro- } \beta \text {-carboline, } \\
\text { and }(-)-(\mathrm{S})-1,2 \text {-dimethyl-1,2,3,4-tetrahydro- } \beta \text {-carboline }\end{array}$ \\
\hline Bidens pilosa & Phenolics, flavonoids, quercetin \\
\hline Carica papaya & $\begin{array}{l}\text { Carotenoids, polyphenols, benzyl isothiocyanates, and benzyl } \\
\text { glucosinates, cyanogenic substance prunasin }\end{array}$ \\
\hline Ranunculus & Saponins, tannins, phenols, flavonoids, and alkaloids \\
\hline $\begin{array}{l}\text { Peltophorum } \\
\text { africanum }\end{array}$ & $\begin{array}{l}\text { peltogynoid ophioglonin, 2-phenoxychromone, 3'-O- } \beta \text {-D-glucoside, } \\
\text { peltogynoid ophioglonin }\end{array}$ \\
\hline Vachellia karroo & Anthroquinones \\
\hline Rhoicissus tridentate & Alkaloids, flavonoids, tannins \\
\hline Houttuynia cordata & Quercetin, isoquercitrin \\
\hline Panax notoginseng & Dammarane-type saponin, flavonoids \\
\hline Nelumbo nucifera & Alkaloids, flavonoids, glycosides, terpenoids, steroids \\
\hline Astragalus & Astragalosides, flavonoids, and polysaccharides \\
\hline $\begin{array}{l}\text { Hypericum } \\
\text { aethiopicum }\end{array}$ & $\alpha$-pinene, $\beta$-pinene, $\alpha$-pinene \\
\hline Spondias mombin & Quercetin, myricetin, and luteolin flavonoids \\
\hline Jatropha zeyheri & $\begin{array}{l}\beta \text {-pinene, 1,3,8-p-menthatriene, ledene, m-menthane, linalyl acetate, } \\
\text { and } 3 \text {-carene. } \beta \text {-sitosterol, lupeol, } \beta \text {-sitosterol, spathulenol, } \\
\beta \text {-sitostenone, } \gamma \text {-sitosterol, and stigmasterol }\end{array}$ \\
\hline Ximenia caffra & Phenolic acid and flavonoids \\
\hline Trichilia dregeana & $\begin{array}{l}\text { Oleanane-type triterpene, } 15 \text {-chloro- } \beta \text {-amyrone, was isolated from } \\
\text { Trichilia hirta, together with the known compounds taraxer-3-one, } \\
\beta \text {-taraxerol, along with two novel esters, } \\
\text { 3-(isobutyryloxy)-2,2,4-trimethylpenty palmitate, } \\
\text { 3-(isobutyryloxy)-2,2,3-trimethylpenty stearate, and the known } \\
\text { 3-hydroxy-2,2,4-trimethylpentyl isobutyrate }\end{array}$ \\
\hline Clematis brachiata & Triterpenoid saponins \\
\hline Tabernaemontana & $\begin{array}{l}\beta \text {-caryophyllene (56.87\%), } \alpha \text {-cadinol (12.52\%), 8S,13-cedran-diol } \\
(5.41 \%), \alpha \text {-terpineol (3.99\%), } \beta \text {-eudesmol, caryophyllene oxide ethyl } \\
\text { iso-allocholate, } \beta \text {-cubebene, curcumenol, spathulenol, friedeline and } \\
\beta \text {-sitosterol, alkaloids, isoakuammiline, } \\
\text { 18-hydroxypseudovincadifformine, alkaloids, coronaridine, } \\
\text { heyneanine, 3,19-oxidocoronaridine, tabersonine, and strictosidine }\end{array}$ \\
\hline Sarcophyton & $\begin{array}{l}\text { Flavanone glycoside, naringenin 5-glucoside. Their structures were } \\
\text { elucidated on spectroscopic evidence as } \\
\text { 5,7,3',4'-tetrahydroxyflavanyl-7-O-beta-glucosyl-(4beta-8; } \\
\text { 2beta-O-7)-eriodietyol 5,7,3',4'-tetrahydroxyflavanyl } \\
\text { 7-O-beta-glucosyl-(4beta-8;2beta-O-7)-naringenin, respectively }\end{array}$ \\
\hline
\end{tabular}

Ref.

phytochemical investigations have indicated that the medicinal plants have antioxidant, antimicrobial, antiviral, and antifungal properties, which may be due to the active 
ingredients and active flavonoids, such as total flavonoids and phenolics, quercetin, isoquercitrin, Dammarane-type saponin, flavonoids, alkaloids, flavonoids, glycosides, terpenoids, steroids, astragalosides, flavonoids and polysaccharides, $\alpha$-pinene, $\beta$-pinene, $\alpha$-pinene, quercetin, myricetin and luteolin flavonoids, $\beta$-pinene, 1,3,8-p-menthatriene, ledene, $m$-menthane, linalyl acetate and 3-carene, $\beta$-sitosterol, lupeol, spathulenol, $\beta$ sitostenone, $\gamma$-sitosterol, stigmasterol, phenolic acid and flavonoids, etc. This article mentions some of the therapeutic and medicinal plants in traditional medicine across the world that have antifungal and antimicrobial properties to treat STIs and genital tract infections. The studies have been conducted to demonstrate the prevention and treatment of genital tract bacterial diseases and STIs in humans by a number of common therapeutic medicinal plants with antibacterial and antioxidant effects and also the pathways in which they act; these medicinal plants may also be used to supply drugs in complementary medicine due to the presence of antioxidant compounds, bioactive compounds, phenols, flavonoids, etc. [86-95, 115-120].

\section{Conflict of Interest}

The authors declared no potential conflicts of interest with respect to the research, authorship, and/or publication of this article.

\section{Authors' Contributions}

All authors searched, studied, reviewed, and contributed to the design of the research equally. All authors reviewed, commented and approved the final draft.

\section{Ethical Approval}

In preparation of this review article we tried to consider all ethical issues.

\section{References}

[1] Wardlaw, A. M. and Agrawal, A. F. (2018). Sexual conflict and sexually transmitted infections (STIS): coevolution of sexually antagonistic host traits with an STI. The American Naturalist, vol. 193, no. 1, p. E000.

[2] Wardlaw, A. M. and Agrawal, A. F. (2018). Sexual conflict and STIs: coevolution of sexually antagonistic host traits with a sexually transmitted infection. bioRxiv, 


\section{.203695}

[3] Weinstock, H., Berman, S., and Cates, Jr., W. (2004). Sexually transmitted diseases among American youth: incidence and prevalence estimates, 2000. Perspectives on Sexual and Reproductive Health, vol. 36, no. 1, pp. .10-6

[4] Hurst, G. D. D., Sharpe, R. G., Broomfield, A. H., et al. (1995). Sexually transmitted disease in a promiscuous insect, Adalia bipunctata. Ecological Entomology, vol. 20, no. 3, pp. .236-230

[5] Fenton, K. A. and Lowndes, C. M. (2004). Recent trends in the epidemiology of sexually transmitted infections in the European Union. Sexually Transmitted Infections, vol. 80, no. 4, pp. .263-255

[6] Gerbase, A. C., Rowley, J. T., and Mertens, T. E. (1998). Global epidemiology of sexually transmitted diseases. The Lancet, vol. 351, pp. S2-S4.

[7] May, R. M. and Anderson, R. M. (1979). Population biology of infectious diseases: Part II. Nature, vol. 280 , no. 5722 , p. .455

[8] Hunt, C. W. (1989). Migrant labor and sexually transmitted disease: AIDS in Africa. Journal of Health and Social Behavior, vol. 30, no. 4, pp. .373-353

[9] Levine, G. I. (1991). Sexually transmitted parasitic diseases. Primary Care, vol. 18, no. 1, pp. .128-101

[10] Santana, N., Santos, T., Sato, A., et al. (2018). Vertical transmission of human papillomavirus in pregnancy: a systematic review and meta-analysis. International Journal of Infectious Diseases, vol. 73, pp. .335-334

[11] Peder, L., Nascimento, B., Plewka, J., et al. (2018). Prevalence and predictors associated with sexually transmitted infections in patients in Southern Brazil. International Journal of Infectious Diseases, vol. 73, p. .335

[12] Giesecke, J. (2017). Modern Infectious Disease Epidemiology. Boca Raton, FL: CRC Press.

[13] Geremew, R. A., Agizie, B. M., and Bashaw, A. A., et al. (2017). Prevalence of selected sexually transmitted infection (STI) and associated factors among symptomatic patients attending Gondar Town hospitals and health centers. Ethiopian Journal of Health Sciences, vol. 27, no. 6, pp. .600-589

[14] Berec, L., Janoušková, E., and Theuer, M. (2017). Sexually transmitted infections and mate-finding Allee effects. Theoretical Population Biology, vol. 114, pp. .69-59

[15] Morris, M. C., Rogers, P. A., and Kinghorn, G. R. (2001). Is bacterial vaginosis a sexually transmitted infection? Sexually Transmitted Infections, vol. 77, no. 1, pp. .68-63

[16] Allsworth, J. E., Lewis, V. A., and Peipert, J. F. (2008). Viral sexually transmitted infections and bacterial vaginosis: 2001-2004 National Health and Nutrition 
Examination Survey data. Sexually Transmitted Diseases, vol. 35, no. 9, pp. 791.796

[17] Fenton, K. A., Korovessis, C., Johnson, A. M., et al. (2001). Sexual behaviour in Britain: reported sexually transmitted infections and prevalent genital Chlamydia trachomatis infection. The Lancet, vol. 358, no. 9296, pp. .1854-1851

[18] Thompson, S. E. and Washington, A. E. (1983). Epidemiology of sexually transmitted Chlamydia trachomatis infections. Epidemiologic Reviews, vol. 5, p. .96

[19] Wasserheit, J. N. (1992). Epidemiological synergy. Interrelationships between human immunodeficiency virus infection and other sexually transmitted diseases. Sexually Transmitted Diseases, vol. 19, no. 2, pp. .77-61

[20] Simonsen, J. N., Cameron, W., Gakinya, M. N., et al. (1988). Human immunodeficiency virus infection among men with sexually transmitted diseases. New England Journal of Medicine, vol. 319, no. 5, pp. .278-274

[21] Desclaux, A., de Lamballerie, X., Leparc-Goffart, I., et al. (2018). Probable sexually transmitted zika virus infection in a pregnant woman. New England Journal of Medicine, vol. 378, no. 15, pp. .1460-1458

[22] Kojima, N. and Klausner, J. D. (2018). Improving management of sexually transmitted infections in those who use pre-exposure prophylaxis for human immunodeficiency virus infection. Aids, vol. 32, no. 2, pp. .275-272

[23] Okumura, C. Y., Baum, L. G., and Johnson, P. J. (2008). Galectin-1 on cervical epithelial cells is a receptor for the sexually transmitted human parasite Trichomonas vaginalis. Cellular Microbiology, vol. 10, no. 10, pp. .2090-2078

[24] Håkansson, C., Thorén, K., Norkrans, G., et al. (1984). Intestinal parasitic infection and other sexually transmitted diseases in asymptomatic homosexual men. Scandinavian Journal of Infectious Diseases, vol. 16, no. 2, pp. .202-199

[25] Conrad, M., Zubacova, Z., Dunn, L. A., et al. (2011). Microsatellite polymorphism in the sexually transmitted human pathogen Trichomonas vaginalis indicates a genetically diverse parasite. Molecular and Biochemical Parasitology, vol. 175, no. 1, pp. .38-30

[26] Carlton, J. M., Hirt, R. P., Silva, J. C., et al. (2007). Draft genome sequence of the sexually transmitted pathogen Trichomonas vaginalis. Science, vol. 315, no. 5809, pp. .212-207

[27] World Health Organization. (2011). Prevalence and incidence of selected sexually transmitted infections, Chlamydia trachomatis, Neisseria gonorrhoeae, syphilis and Trichomonas vaginalis: methods and results used by WHO to generate 2005 estimates. Geneva: World Health Organization. 
[28] Van Der Pol, B. (2007). Trichomonas vaginalis infection: the most prevalent nonviral sexually transmitted infection receives the least public health attention. Clinical Infectious Diseases, vol. 44, no. 1, pp. .25-23

[29] Stemmer, S. M., Mordechai, E., Adelson, M. E., et al. (2018). Trichomonas vaginalis is most frequently detected in women at the age of peri-/premenopause: an unusual pattern for a sexually transmitted pathogen. American Journal of Obstetrics and Gynecology, vol. 218, no. 3, pp. 328.e1-328, e13.

[30] Wang, C. C., McClelland, R. S., Reilly, M., et al. (2001). The effect of treatment of vaginal infections on shedding of human immunodeficiency virus type 1. The Journal of Infectious Diseases, vol. 183, no. 7, pp. .1022-1017

[31] Sobel, J. D. (1990). Vaginal infections in adult women. Medical Clinics of North America, vol. 74, no. 6, pp. .1602-1573

[32] Abdelaziz, Z. A., Ibrahim, M. E., Bilal, N. E., et al. (2014). Vaginal infections among pregnant women at Omdurman Maternity Hospital in Khartoum, Sudan. The Journal of Infection in Developing Countries, vol. 8, no. 4, pp. .497-490

[33] Balkus, J. E., Manhart, L. E., Lee, J., et al. (2016). Periodic presumptive treatment for vaginal infections may reduce the incidence of sexually transmitted bacterial infections. The Journal of Infectious Diseases, vol. 213, no. 12, pp. .1937-1932

[34] Alcaide, M. L., Strbo, N., Romero, L., et al. (2016). Bacterial vaginosis is associated with loss of gamma delta $T$ cells in the female reproductive tract in women in the Miami Women Interagency HIV Study (WIHS): A cross sectional study. PLOS ONE, vol. 11, no. 4, pp. e0153045.

[35] Chen, C., Song, X., Wei, W., et al. (2017). The microbiota continuum along the female reproductive tract and its relation to uterine-related diseases. Nature Communications, vol. 8 , no. 1, p. .875

[36] Fridkin, S. K. and Jarvis, W. R. (1996). Epidemiology of nosocomial fungal infections. Clinical Microbiology Reviews, vol. 9, no. 4, pp. .511-499

[37] De Bernardis, F., Liu, H., O'Mahony, R., et al. (2007). Human domain antibodies against virulence traits of Candida albicans inhibit fungus adherence to vaginal epithelium and protect against experimental vaginal candidiasis. The Journal of Infectious Diseases, vol. 195, no. 1, pp. .157-149

[38] Badiee, P., Kordbacheh, P., Alborzi, A., et al. (2005). Fungal infections in solid organ recipients. Experimental and Clinical Transplantation, vol. 3, no. 2, pp. .389-385

[39] Witkin, S. S. (2015). The vaginal microbiome, vaginal anti-microbial defence mechanisms and the clinical challenge of reducing infection-related preterm birth. 
BJOG: An International Journal of Obstetrics \& Gynaecology, vol. 122, no. 2, pp. $.218-213$

[40] Passmore, J.-A. S. and Jaspan, H. B. (2018). Vaginal microbes, inflammation, and HIV risk in African women. The Lancet Infectious Diseases, vol. 18, no. 5, pp. .484-483

[41] Donati, L., Di Vico, A., Nucci, M., et al. (2010). Vaginal microbial flora and outcome of pregnancy. Archives of Gynecology and Obstetrics, vol. 281, no. 4, pp. .600-589

[42] Azu, M. N., Richter, S., and Aniteye, P. (2018). Ghanaian men living with sexual transmitted infections: knowledge and impact on treatment seeking behaviour-a qualitative study. African Journal of Reproductive Health, vol. 22, no. 3, pp. .32-24

[43] Desmennu, A. T., Titiloye, M. A., and Owoaje, E. T. (2018). Behavioural risk factors for sexually transmitted infections and health seeking behaviour of street youths in Ibadan, Nigeria. African Health Sciences, vol. 18, no. 1, pp. .187-180

[44] Mulaudzi, R. B., Ndhlala, A. R., and Van Staden, J. (2015). Ethnopharmacological evaluation of a traditional herbal remedy used to treat gonorrhoea in Limpopo province, South Africa. South African Journal of Botany, vol. 97, pp. .122-117

[45] Ozen, B. and Baser, M. (2017). Vaginal candidiasis infection treated using apple cider vinegar: a case report. Alternative Therapies in Health \& Medicine, vol. 23, no. .7

[46] Hayajneh, F. M. F., Jalal, M., Zakaria, H., et al. (2018). Anticoccidial effect of apple cider vinegar on broiler chicken: an organic treatment to measure anti-oxidant effect. Polish Journal of Veterinary Sciences, vol. 21, no. 2, pp. .369-361

[47] Khezri, S. S., Saidpour, A., Hosseinzadeh, N., et al. (2018). Beneficial effects of apple cider vinegar on weight management, Visceral Adiposity Index and lipid profile in overweight or obese subjects receiving restricted calorie diet: a randomized clinical trial. Journal of Functional Foods, vol. 43, pp. .102-95

[48] Press, S. (2015). Do-it-yourself herbal medicine: home-crafted remedies for health and beauty. Berkeley, CA: Arcas Publishing.

[49] Luqman, S., Dwivedi, G. R., Darokar, M. P., et al. (2007). Potential of rosemary oil to be used in drug-resistant infections. Alternative Therapies in Health \& Medicine, vol. 13 , no. 5 , pp. .59-54

[50] Jiang, Y., Wu, N., Fu, Y. J., et al. (2011). Chemical composition and antimicrobial activity of the essential oil of rosemary. Environmental Toxicology and Pharmacology, vol. 32 , no. 1 , pp. .68-63

[51] Issabeagloo, E., Kermanizadeh, P., Taghizadieh, M., et al. (2012). Antimicrobial effects of rosemary (Rosmarinus officinalis L.) essential oils against Staphylococcus spp. African Journal of Microbiology Research, vol. 6, no. 23, pp. .5042-5039 
[52] Ojeda-Sana, A. M., van Barenb, C. M., Elechosa, M. A., et al. (2013). New insights into antibacterial and antioxidant activities of rosemary essential oils and their main components. Food Control, vol. 31, no. 1, pp. .195-189

[53] Mohsenipour, Z. and Hassanshahian, M. (2015). The effects of Allium sativum extracts on biofilm formation and activities of six pathogenic bacteria. Jundishapur Journal of Microbiology, vol. 8, no. 8, e18971.

[54] Mahady, G. B. (2005). Medicinal plants for the prevention and treatment of bacterial infections. Current Pharmaceutical Design, vol. 11, no. 19, pp. .2427-2405

[55] Goncagul, G. and Ayaz, E. (2010). Antimicrobial effect of garlic (Allium sativum). Recent Patents on Anti-infective Drug Discovery, vol. 5, no. 1, pp. .93-91

[56] Oloke, J., Odelade, K., and Oladeji, O. (2017). Characterization and antimicrobial analysis of flavonoids in vernonia amygdalina: a common chewing stick in southwestern Nigeria. Bulletin of Pharmaceutical Research, vol. 7, no. 3, p. 149

[57] Markum, E. and Baillie, J. (2012). Combination of essential oil of Melaleuca alternifolia and iodine in the treatment of molluscum contagiosum in children. Journal of Drugs in Dermatology, vol. 11, no. 3, pp. .354-349

[58] Fouladvand, M., Khorami, S., Naeimi, B., et al. (2016). Evaluation of in vitro leishmanicidal activity of tea tree oil (Melaleuca alternifolia). Tibb-i junūb, vol. 18, no. 6 , pp. .1269-1262

[59] Sinha, D. J., Vasudeva, A., Gowhar, O., et al. (2015). Comparison of antimicrobial efficacy of propolis, Azadirachta indica (Neem), Melaleuca alternifolia (Tea tree oil), Curcuma longa (Turmeric) and 5\% sodium hypochlorite on Candida albicans biofilm formed on tooth substrate: an in-vitro study. Journal of Pharmaceutical and Biomedical Sciences, vol. 5, no. 6, pp. .474-469

[60] Eldin, H. M. E. and Badawy, A. F. (2015). In vitro anti-Trichomonas vaginalis activity of Pistacia lentiscus mastic and Ocimum basilicum essential oil. Journal of Parasitic Diseases, vol. 39, no. 3, pp. .473-465

[61] Loughrin, J. H. and Kasperbauer, M. J. (2001). Light reflected from colored mulches affects aroma and phenol content of sweet basil (Ocimum basilicum L.) leaves. Journal of Agricultural and Food Chemistry, vol. 49, no. 3, pp. .1335-1331

[62] Kayode, J. and Kayode, G. M. (2008). Ethnomedicinal survey of botanicals used in treating sexually transmitted diseases in Ekiti State, Nigeria. Ethnobotanical Leaflets, vol. 2008 , no. 1 , p. .7

[63] Zandi, K., Zadeh, M. A., Sartavi, K., et al. (2007). Antiviral activity of aloe Vera against herpes simplex virus type 2: an in vitro study. African Journal of Biotechnology, vol. 6 , no. 15 
[64] Talwar, G. P. (2018). Development of a unique polyherbal formulation BASANT endowed with wide spectrum action on sexually transmitted infections and capability of restoring healthy vagina. SciFed Journal of Herbal Medicine, vol. 2, no. .1

[65] Haroon, S. M., Shahid, S., Ammar Hussain, S., et al. (2018). Comparative Study of Antioxidant Activity of Flower of Aloe vera and Leaf Extract of Aloe ferox. Journal of Basic and Applied Sciences, vol. 14, pp. .196-191

[66] Sushen, U., Unnithan, C. R., Rajan, S., et al. (2017). Aloe vera: a potential herb used as traditional medicine by tribal people of Kondagatu and Purudu of Karimnagar District, Telangana state, India. and their preparative methods. European Journal of Pharmaceutical and Medical Research, vol. 4, no. 7, pp. .831-820

[67] Mgbeje, B. I. O., Asenye, E. M., Iwara, I. A., et al. (2016). Antihyperglycemic and antihyperlipidemic properties of $n$-hexane fraction of Heinsia crinita crude leaf extracts. World Journal of Pharmacy and Pharmaceutical Sciences, vol. 5, no. 10, pp. .197-185

[68] Rezaie, P., Mazidi, M., and Nematy, M. (2015). Ghrelin, food intake, and botanical extracts: a review. Avicenna Journal of Phytomedicine, vol. 5, no. 4, p. .271

[69] Dinda, B., Kyriakopoulos, A. M., Dinda, S., et al. (2016). Cornus mas L.(cornelian cherry), an important European and Asian traditional food and medicine: ethnomedicine, phytochemistry and pharmacology for its commercial utilization in drug industry. Journal of Ethnopharmacology, vol. 193, pp. .690-670

[70] Moldovan, B., Filip, A., Clichici, S., et al. (2016). Antioxidant activity of Cornelian cherry (Cornus mas $L$.) fruits extract and the in vivo evaluation of its anti-inflammatory effects. Journal of Functional Foods, vol. 26, pp. 77-87.

[71] Webberley, K. M. and Hurst, G. D. (2002). The effect of aggregative overwintering on an insect sexually transmitted parasite system. Journal of Parasitology, vol. 88, no. 4 , pp. .712-707

[72] Ayehunie, S., Wang, Y.-Y., Landry, T., et al. (2018). Hyperosmolal vaginal lubricants markedly reduce epithelial barrier properties in a three-dimensional vaginal epithelium model. Toxicology Reports, vol. 5, pp. .140-134

[73] Deryabin, D. G. and Tolmacheva, A. A. (2015). Antibacterial and anti-quorum sensing molecular composition derived from quercus cortex (oak bark) extract. Molecules, vol. 20 , no. 9 , pp. .17108-17093

[74] Chahardooli, M. and Khodadadi, E. (2014). The biosynthesis of silver nanoparticles using OAK fruit extract and the investigation of their anti-microbial activities against nosocomial infection agents. Scientific Journal of Ilam University of Medical Sciences, vol. 22, no. 4, pp. 27-33 [in Persian]. 
[75] Abu-Jafar, A. and Huleihel, M. (2017). Antiviral activity of Eucalyptus camaldulensis leaves ethanolic extract on herpes viruses infection. International Journal of Clinical Virology, vol. 1, pp. 1-9.

[76] Maroyi, A. (2017). Exotic plants in indigenous pharmacopoeia of south-central Zimbabwe: traditional knowledge of herbal medicines. Research Journal of Botany, vol. 12 , no. 2 , pp. .52-46

[77] Ghareeb, M. A., Habib, M. R., Mossalem, H. S., et al. (2018). Phytochemical analysis of Eucalyptus camaldulensis leaves extracts and testing its antimicrobial and schistosomicidal activities. Bulletin of the National Research Centre, vol. 42, no. 1, p. .16

[78] Trivedi, J., et al. (2019). "Plant-Derived Molecules in Managing HIV Infection," in New Look to Phytomedicine, pp. 273-298. Cambridge, MA: Academic Press.

[79] Ryz, N. R., Remillard, D. J., and Russo, E. B. (2017) Cannabis roots: a traditional therapy with future potential for treating inflammation and pain. Cannabis and Cannabinoid Research, vol. 2, no. 1, pp. .216-210

[80] Ashfaq, U. A., Javed, T., Rehman, S., et al. (2011). Inhibition of HCV 3a core gene through Silymarin and its fractions. Virology Journal, vol. 8, no. 1, p. .153

[81] Menéndez-Perdomo, I. M. and Sánchez-Lamar, Á. (2017). Phyllanthus plants in photoprotection: a broad spectrum of molecular mechanisms. Pharmacophore, vol. 8, no. .3

[82] Dashtdar, M., Dashtdar, M. R., Dashtdar, B., et al. (2013). In-vitro, anti-bacterial activities of aqueous extracts of Acacia catechu (LF) Willd, Castanea sativa, Ephedra sinica stapf and shilajita mumiyo against Gram positive and Gram negative bacteria. Journal of Pharmacopuncture, vol. 16, no. 2: pp. .22-15

[83] Caveney, S., Charlet, D. A., Freitag, H., et al. (2001). New observations on the secondary chemistry of world Ephedra (Ephedraceae). American Journal of Botany, vol. 88, no. 7, pp. .1208-1199

[84] Kmail, A., Lyoussi, B., Zaidet, H., et al. (2017). In vitro evaluation of anti-inflammatory and antioxidant effects of Asparagus aphyllus L., Crataegus azarolus L., and Ephedra alata Decne. in monocultures and co-cultures of HepG2 and THP-1-derived macrophages. Pharmacognosy Communications, vol. 7, no. 1, p. .24

[85] Kallassy, H. Phytochemistry and biological activities of selected Lebanese plant species (Crataegus azarolus L. and Ephedra campylopoda). PhD Thesis. Université de Limoges, Université Libanaise (Liban), .2017 
[86] Park, S. B., Park, G. H., Kim, H. N., et al. (2018). Anti-inflammatory effect of the extracts from the branch of Taxillus yadoriki being parasitic in Neolitsea sericea in LPS-stimulated RAW264.7 cells. Biomedicine \& Pharmacotherapy, vol. 104, pp. .7-1

[87] Wink, M. (2012). Medicinal plants: a source of anti-parasitic secondary metabolites. Molecules, vol. 17, no. 11, pp. .12791-12771

[88] Thirumurugan, K. (2010). Antimicrobial activity and phytochemical analysis of selected Indian folk medicinal plants. Steroids, vol. 1, p. .7

[89] Naidoo, D., van Vuuren, S. F., van Zyl, R. L., et al. (2013). Plants traditionally used individually and in combination to treat sexually transmitted infections in northern Maputaland, South Africa: antimicrobial activity and cytotoxicity. Journal of Ethnopharmacology, vol. 149, no. 3, pp. 656-667.

[90] Te, T., Mamba, P., and Adebayo, S. A. (2016). Antimicrobial, antioxidant and cytotoxicity studies of medicinal plants used in the treatment of sexually transmitted diseases. International Journal of Pharmacognosy and Phytochemical Research, vol. 8, no. 11, pp. .1895-1891

[91] Li, W., Wang, X.-H., Luo, Z., et al. (2018). Traditional Chinese medicine as a potential source for HSV-1 therapy by acting on virus or the susceptibility of host. International Journal of Molecular Sciences, vol. 19, no. 10, p. 3266.

[92] Van Vuuren, S. and Naidoo, D. (2010). An antimicrobial investigation of plants used traditionally in southern Africa to treat sexually transmitted infections. Journal of Ethnopharmacology, vol. 130, no. 3, pp. 552-558.

[93] Samba, B. M., Kabiné, O., Sahar, T. M., et al. (2015). Evaluation of antibacterial activity of some medicinal plants used in the treatment of sexually transmitted infections (STI) in Guinean traditional medicine. Journal of Plant Sciences, vol. 3, no. 1-2, pp. 6-10.

[94] Mongalo, N., McGaw, L., Finnie, J., et al. (2017). Pharmacological properties of extracts from six South African medicinal plants used to treat sexually transmitted infections (STIs) and related infections. South African Journal of Botany, vol. 112, pp. 290-295.

[95] Naidoo, D., Van Vuuren, S., Van Zyl, R., et al. (2013). Plants traditionally used individually and in combination to treat sexually transmitted infections in northern Maputaland, South Africa: antimicrobial activity and cytotoxicity. Journal of Ethnopharmacology, vol. 149, no. 3, pp. 656-667.

[96] Aberg, J. A., Gallant, J. E., Ghanem, K. G., et al. (2004). Primary care guidelines for the management of persons infected with human immunodeficiency virus: recommendations of the HIV Medicine Association of the Infectious Diseases Society of America. Clinical Infectious Diseases, vol. 39, no. 5, pp. .629-609 
[97] Ndubani, P. and Höjer, B. (1999). Traditional healers and the treatment of sexually transmitted illnesses in rural Zambia. Journal of Ethnopharmacology, vol. 67, no. 1, pp. .25-15

[98] Zachariah, R., Nkhoma, W., Harries, A. D., et al. (2002). Health seeking and sexual behaviour in patients with sexually transmitted infections: the importance of traditional healers in Thyolo, Malawi. Sexually Transmitted Infections, vol. 78, no. 2, pp. .129-127

[99] Green, E. C., Jurg, A., and Dgedge, A. (1993). Sexually-transmitted diseases, AIDS and traditional healers in Mozambique. Medical Anthropology, vol. 15, no. 3, pp. $.281-261$

[100] Workowski, K. A. and Bolan, G. A. (2015). Sexually transmitted diseases treatment guidelines, 2015. MMWR. Recommendations and reports: morbidity and mortality weekly report. Recommendations and Reports, vol. 64, RR-03, p. .1

[101] Van Der Pol, B., Williams, J. A., Orr, D. P., et al. (2005). Prevalence, incidence, natural history, and response to treatment of Trichomonas vaginalis infection among adolescent women. The Journal of Infectious Diseases, vol. 192, no. 12, pp. 2039_ .2044

[102] Baseman, J. G. and Koutsky, L. A. (2005). The epidemiology of human papillomavirus infections. Journal of Clinical Virology, vol. 32, pp. .24-16

[103] Tajallaie-Asl, F., Mardani, M., Shahsavari, S., et al. (2017). Menstruation phytotherapy according to Iran ethnobotanical sources. Journal of Pharmaceutical Sciences and Research, vol. 9, no. 6, pp. .990-986

[104] Moradi, B., Abbaszadeh, S., Shahsavari, S., et al. (2018). The most useful medicinal herbs to treat diabetes. Biomedical Research and Therapy, vol. 5, no. 8, pp. 2538.2551

[105] Naghdi, N. (2018). Folklore medicinal plants used in liver disease: a review. International Journal of Green Pharmacy, vol. 12, no. .3

[106] Van Vuuren, S. F. (2008). Antimicrobial activity of South African medicinal plants. Journal of Ethnopharmacology, vol. 119, no. 3, pp. .472-462

[107] Shale, T. L., Stirk, W. A., and Van Staden, J. (1999). Screening of medicinal plants used in Lesotho for anti-bacterial and anti-inflammatory activity. Journal of Ethnopharmacology, vol. 67, no. 3, pp. .354-347

[108] Prasad, D. M. R., Izam, A., Khan, Md. M. R. (2012). Jatropha curcas: plant of medical benefits. Journal of Medicinal Plants Research, vol. 6, no. 14, pp. .2699-2691 
[109] Naidoo, D. (2014). Safety and efficacy of traditional medicinal plant combinations for the treatment of sexually transmitted infections in Northern Maputaland, South Africa. PhD Thesis.

[110] Tibiri, A., Sawadogo, W. R., Dao, A., et al. (2015). Indigenous Knowledge of Medicinal Plants Among Dozo Hunters: An Ethnobotanical Survey in Niamberla Village, Burkina Faso. The Journal of Alternative and Complementary Medicine, vol. 21, no. 5, pp. .303-294

[111] Malterud, K. (2017). Ethnopharmacology, chemistry and biological properties of four Malian medicinal plants. Plants, vol. 6, no. 1, p. .11

[112] Chaleshtori, S., Rokni, N., Rafieian-kopaei, M., et al. (2015). Antioxidant and antibacterial activity of basil (Ocimum basilicum L.) essential oil in beef burger. Journal of Agricultural Science and Technology, vol. 17, no. 4, pp. 817-826.

[113] Ghamari, S., Abbaszadeh, S., Mardani, M., et al. (2017). Identifying medicinal plants affecting the teeth from the Southern district of Ilam province, Iran. Journal of Pharmaceutical Sciences and Research, vol. 9, no. 6, p. 800.

[114] Ghasemi Pirbalouti, A., Momeni, M., and Bahmani, M. (2013). Ethnobotanical study of medicinal plants used by Kurd tribe in Dehloran and Abdanan Districts, Ilam province, Iran. African Journal of Traditional, Complementary and Alternative Medicines, vol. 10, pp. 368-385.

[115] Moayeri, A., Azimi, M., Karimi, E., et al. (2018). Attenuation of morphine withdrawal syndrome by prosopis farcta extract and its bioactive component luteolin in comparison with clonidine in rats. Medical Science Monitor Basic Research, vol. 24, pp. 151-158.

[116] Bahmani, M., Khaksarian, M., Rafieian-Kopaei M, et al. (2018). Overview of the therapeutic effects of origanum vulgare and hypericum perforatum based on Iran's ethnopharmacological documents. Journal of Clinical and Diagnostic Research, vol. 12, no. 7, pp. 1-4.

[117] Tajbakhsh, M., Karimi, A., Tohidpour, A., et al. (2018). The antimicrobial potential of a new derivative of cathelicidin from Bungarus fasciatus against methicillin-resistant Staphylococcus aureus. Journal of Microbiology, vol. 56, no. 2, pp. 128-137.

[118] Abbasi, N., Mohammadpour, S., Karimi, E., et al. (2017). Protective effects of Smyrnium cordifolium Boiss essential oil on pentylenetetrazol-induced seizures in mice: Involvement of benzodiazepine and opioid antagonists. Journal of Biological Regulators and Homeostatic Agents, vol. 31, pp. 683-689.

[119] Faryadian, S., Sydmohammadi, A., Khosravi, A., et al. (2014). Aqueous extract of echium amoenum elevate csf serotonin and dopamine level in depression 
rat. Biomedical and Pharmacology Journal, vol. 7, no. 1. Retrieved from: http: //biomedpharmajournal.org/?p=2875

[120] Shokri, Z., Khoshbi, M., Koohpayeh, A., et al. (2018). Thyroid diseases: pathophysiology and new hopes in treatment with medicinal plants and natural antioxidants. International Journal of Green Pharmacy, vol. 12, no. 3, pp. 473-483. 